\title{
Teachers' Perceptions and Value of Yoruba as a Medium of Instruction in Primary 3 Classes
}

\author{
Babajide Gboyega Abidogun, Nkidi Phatudi, Ina Joubert and Cycil Hartell \\ Department of Early Childhood Education Faculty of Education, University of Pretoria, \\ South Africa \\ "E-mail: $\underline{\text { koricson@gmail.com }}$
}

\begin{abstract}
Yoruba is one of the languages recognised in Nigeria to be used as medium of instruction in the lower primary classes as stipulated by the Nigerian National Policy on Education. This study investigated how teachers experience the use of Yoruba as medium of instruction in primary classes. The study was qualitative thus employed the one-on-one interview schedule, semi- structured observation schedule and document analysis as data collection instruments. The participants included 10 primary three teachers in two primary schools. The findings revealed amongst others that despite lack of support from the government teachers have taken it upon themselves to promote Yoruba and make it accessible to learners. The study recommended that the government should do more to provide workshops and relevant materials for teaching.
\end{abstract}

KEYWORDS Teachers. Perception. Values. Yoruba. Medium of Instruction. Primary Classes

\section{INTRODUCTION}

When learners are given opportunities to learn in their mother tongue, they are more likely to succeed in classrooms (Kosonen 2005) and their parents are likely to communicate with teachers and get involved in their children's learning (Benson 2002). Ball (2010) argues that six to eight years of education in mother tongue are essential to develop the literacy and verbal proficiency level of learners required for academic achievement in schools. Furthermore, Ball (2010) asserts that literacy in the mother tongue allows for linguistic foundation for learning additional languages.

Summer Institute of Linguistics (SIL) (1999) asserts that mother tongue education involves the use of mother tongue for formal education. To use a language different from the language of the society as a medium of instruction can create a gap which can further be widened when the curriculum, syllabus, teaching methodology and content of lessons run contrary to the stipulated policy (FRN 2004). If the curriculum, syllabus and content of lessons are all written in English 
instead of mother tongue in Nigeria, it could lead to learning problems and poor academic performance (Iyamu and Ogiegbaen 2005). Mother tongue provides a rewarding school learning and experience which can be a continuation of home experience that guarantees cognitive equilibrium (Iyamu and Ogiegbaen 2005).

The Nigerian National Policy on Education (FRN 2004) prescribes the use of mother tongue as a medium of instruction in the Grades $1-3$ at the lower primary schools. Mother tongue instruction enjoys considerable popularity and acceptance in educational circles because it provided a natural and effective way of communication as well as closing the gap between the child's home and the school (Cummins 2001).

On the other hand, Gupta (1997) states that the use of the mother tongue does not necessarily lead to better education. Instead mother tongue instruction is used to perpetuate the cycle of class distinction. He says it is only the poor who are subjected to the use of the language while the rich and elites make use of the official language to communicate and transact business. However, one needs to investigate how teachers perceive Yoruba as a medium of instruction and the experiences they encounter in their day to day teaching.

\section{Problem Statement}

Yoruba language like other indigenous languages has been facing a lot of challenges particularly as a language of learning and teaching (LOLT). It should be noted that the implementation of mother-tongue as a medium of instruction is both demanding and expensive. It entails a lot of resources to produce teaching and learning materials and to train teachers. Currently, no concrete efforts have been made by the Nigerian government to face the challenges of implementing the mother-tongue medium policy. According to Urevbu (2001), the requirements for the implementation include linguistic analysis of the phonology and grammar of the language; devising a practical orthography, and preparing and testing of primers and readers as well as supplementary reading materials. At present, these have not been provided.

Kalu (1990) questioned the practicality and cost effectiveness of producing materials and teachers in all the indigenous languages in Nigeria. Olowoyo (1990) argued that the indigenous languages are not developed to welcome new concepts, ideas, formulae, theory and scientific terms that have their origin in the western world. Against this background, learner's ability to 
speak Yoruba fluently in primary schools in Lagos State has been impeded. Therefore, given the status of Yoruba, this study investigated teachers' experiences using Yoruba as a medium of instruction in primary schools in Lagos State Nigeria and its implications on primary 3 learners.

\section{Research Question}

This study was guided by this research question:

- What are the experiences of teachers when using Yoruba as a medium of instruction in primary school classes?

\section{Literature Review}

Literature in mother tongue instruction has been two faced about the role and importance of mother tongue instruction in enhancing the language development of children. This literature speaks for the use of the mother tongue, and there have been counteracting voices that are against the use of the mother tongue. Below is the discussion of the discourses that supports and are against the use of the mother tongue instruction in school.

\section{Discourse in Support of the Mother Tongue}

Mother tongue instruction in the first years of schooling has been lauded as beneficial in using and understanding the classroom context. Dutcher (2003) argues that children who begin their education with mother tongue as the language of instruction perform better that those who begin their schooling in another language other than the indigenous one. Explaining further, Dutcher (2003) mentions that academic achievement can be attained when mother tongue is used as a basis for learning additional languages.

The successful use of mother tongue instruction in the classroom depends on the teachers and the support they receive from other stakeholders within and outside the education system (Chilora and Harris 2001). Teachers played significant roles in the implementation of both mother tongue instruction policy and other educational reforms at the classroom level (Littlewood 1981; Wright 1987). Discussion on the use of the mother tongue as a veritable instrument for teaching and 
learning in schools was espoused by Ross (2004) and Fafunwa (1977) when he mentioned that mother tongue education develops the cognitive, affective and psychomotor development of learners in class.

\section{Discourse Against the Use of the Mother Tongue}

Speaking against the use of indigenous language in Kenya, for instance, Gupta (1997) mentions that the diversity of these languages makes it very expensive to provide each child with education in her/his mother tongue. He argues that home language education can cause disunity in a country which may result in extensive separation of ethnic groups in the education system. Gupta (1997) furthermore argued that mother tongue instruction perpetuates class distinction as it is only applied and used by the poorer sectors of the population.

Some scholars describe indigenous languages as primitive idioms with limited communicative value, only to be spoken by illiterate hunters, farmers or cattle rearers and for highly restricted cultural matters only; African languages are not to be used for any advanced nor written communication pertaining to the political, economic, cultural, and social matters of our times, in particular not for anything to do with modern technology, science, and political philosophy (Woolman 2001; Wolff 2005).

It was also identified by Yadav (1992) in the case of Nepal that to produce textbooks in various indigenous languages is expensive and Herculean, hence mother tongue education may be a mirage. Bamgbose (2011) posits that to maintain two or more indigenous languages in a multi linguistic society is a difficult task and more expensive when compared with the use of one official language that may be foreign to the people.

The study conducted was aimed at finding how teachers navigate the teaching terrain within the context explained above.

\section{Theoretical Framework and Related Concepts}

This study is underpinned by different theories and concepts as it cannot be situated within one lens of understanding. The theories and concepts below are discussed according to their importance in influencing and shaping experiences teachers acquire during their course of duty. 
Lived experience referred to a number of temporal, spatial organizations that involves our immediate consciousness of life prior to reflection (Dilthey 1985; Sartre 1957). Lived experience exists only in its representation and does not exist outside of memory (Denzin 1992). The relationship between memory and the lived experience is at the center of knowledge production in order for us to understand people's important places. However, to understand peoples' lived experiences and how their important places are represented through the sharing of their stories, the role of memory and processes of remembering need further explanation (Barkley 2008). Lived experiences are largely influenced by the media, politics and social factors. If the media is critical of the status of languages, this may affect teachers on how they value the language. The use of the language in the society, the respect the language enjoys is bound to reflect on how the language is taught in class.

Teachers are individuals whose identity is determined by the value they attach to the language. Erikson (1968) describes identity as the result from a dynamic interplay between individual and context. He mentions that this interplay is a universal phenomenon, but he also argues that the historical actuality of the wider cultural context sets parameters that individuals can count on during the process of identity development. Therefore, media, society and politics can also have a bearing on an individuals' identity. Learners are influenced by teachers through the way and manner he/she teaches in class and his/her respect for the language. Skutnabb-Kangas (1981) endorses the teaching of mother tongue in the first six years of schooling and further argues that mother tongue offers learners an opportunity to learn the second language.

Funds of knowledge as a concept provide a genuine way for teachers to discover the richness in learners' lives and interests while collaborating with parents in learners' learning, thereby reducing the disjuncture between homes and school (Aubrey 1997; Cumming 2003; Fleer 1997; Loveridge 2004). A language teacher's decisions are important because during teaching, learners bring many experiences, ideas, questions, and knowledge from beyond the classroom; teachers have to include these experiences in ways that help learners understand, participate, and experience language in meaningful ways (Barton and Yang 2000; Oakes 1985, 1990, 2000). New knowledge can be acquired through communal sharing of ideas, experiences, and prior knowledge in an environment (Lave and Wegner 1993), such as the language classroom.

In this paper, we are going to report on the values teachers hold on the importance of Yoruba as a language of the immediate environment in Lagos State, Nigeria. 


\section{METHODOLOGY}

The research is qualitative in nature. We employed this inquiry through an interpretative paradigm. Creswell (2007) argues that qualitative research is a form of research in which researchers make an interpretation of what they see, hear and understand. The researchers also employed a case study design to describe, explain and explore the teachers' experiences in using Yoruba as a medium of instruction in primary schools and its implications to learning in Lagos State, Nigeria (Hancock and Algozzine 2006).

This study focused on primary three teachers and learners in schools in Lagos State, Nigeria. We chose Lagos State as the study area because it is located in the South-West Geo-political zone of Nigeria and the language of the immediate environment is Yoruba. We used two (2) primary schools in Lagos State to enable us to do an in-depth investigation. A total of one hundred and thirty- eight (138) learners took part in this study while a total of four (4) classroom teachers, two (2) head teachers and four (4) assistant head teachers were involved in this study. The head teachers and assistant head teachers are also classroom teachers. The number of primary three teachers was determined by the number of primary three classes found in the schools. The two primary schools purposively chosen for this study are located in Agege Local Government Education Authorities and Badagry Local Government Education Authorities respectively.

The researchers used multiple methods of data collection including interviews to gather information from the teachers of the primary three learners and observation to know how the teachers use Yoruba in teaching. Semi-structured one-to-one interviews were utilized to gather information from primary three teachers and non-participant classroom observation of the learners was used to understand the effect of learning in Yoruba. The National Policy on Education (FRN 2004) document was also analysed to confirm whether the teachers follow and obey the stipulations regarding the use of mother tongue as a medium of instruction in lower primary classes. The instruments explained above assisted me in answering the research question and enabled me to present richly descriptive and detailed data.

Data was analysed according to themes that emerged from the study. These themes were further subdivided into categories which are analysed. Creswell (2007) claimed that data analysis in qualitative research consists of preparing and organising the data for analysis, then reducing the data into themes through a process of coding and condensing the codes, and finally representing 
the data in figures, tables or a discussion. The study was founded on literature reviewed, conceptual and theoretical framework, which included the two schools thoughts on mother tongue instruction, the identity theory, lived experiences and funds of knowledge which are pertinent to the understanding of the mother tongue instruction.

\section{FINDINGS}

These findings are part of a larger study conducted. Only data related to the themes "enjoyment when teaching Yoruba" and "challenges regarding the teaching of Yoruba" will be discussed here. The themes are crucial in the explication of the values teachers held with regard to the teaching Yoruba. Despite challenges teachers met such as lack of appropriate Yoruba books for all learners, and lack of support from the government, they lauded the importance of enjoying teaching Yoruba. However, debilitating conditions also affected the manner and importance they held for language but teachers were not discouraged by these conditions but identified with the language and made use of improvised materials during lessons. The knowledge of subject content was found to be an important component that added to the 'enjoyment of teaching Yoruba'. The proficiency in content knowledge was lauded as closely related to how Yoruba was taught and learned. Lack of support such as textbooks and the curriculum and the abject state of schools are some of the factors that seemed to impact on the teachers' views with regard to the sustainability of the language in their experience of teaching the language. The researchers will present their findings using the theme "enjoyment when teaching Yoruba" and this will be followed by the theme "challenges regarding the teaching of Yoruba"

\section{Theme 1 - Enjoyment when teaching Yoruba}

The following categories are used

\section{Content Knowledge of Yoruba}

The values teachers attach to the teaching of Yoruba in the classroom are reflected in the way they teach. These values are transmitted to learners through a language such as Yoruba and it 
reveals the ways learners internalise the culture and traditions transmitted to them by the teachers.

The teachers used in the study agreed that they need to impact the knowledge and values embedded in Yoruba language into learners and also when they teach other subjects in Yoruba. This is expressed by teacher Jide Sch A, teacher Gbenga Sch A and teacher Gbemi Sch B below. Teacher Jide SchA (Badagry) commented:

When I teach Bible Knowledge using Yoruba as a language of instruction for example, I tried to let the learners know the importance of the moral values embedded in it which they ought to emulate.

Teacher Gbemi Sch B (Agege) also expressed her mind thus:

Whenever I teach, I enjoy teaching Yoruba because it gives me joy and opportunity to share my knowledge and experience acquired over time with the learners.

The above category revealed that teachers' knowledge of the subject matter assisted in making learning and teaching valuable and interesting. The knowledge acquired by the teachers from the cultural backgrounds and their professional and academic achievement helps to form their funds of knowledge. However, sometimes the teachers found it difficult to impact content knowledge to learners. The multilingual nature of the class can also be a hindrance in teaching Yoruba.

\section{Strategies for Teaching Yoruba}

Some of the strategies used by the teachers to teach Yoruba as revealed in this study included songs, proverbs, rhymes, poems and dance. This was supported by the literature which explains that values can be transmitted to the child through oral tradition, proverbs, songs, rhymes, poems, dance and stories (Adeosun 2008). In this section, teachers' strategies used for teaching Yoruba is elaborated by outlining teachers' expressions when interviewed on their strategies and examples of these strategies observed.

The comments of teacher Bisi Sch A, and Gbemi Sch B are outlined below.

Teacher Bisi Sch A (Badagry) said:

Values are transmitted through proverbs, idioms stories and dramatic plays. I use "alo apamo" which are riddles in Yoruba to teach and evaluate learners' cognitive knowledge and cultural awareness. For example “oruku tindi tindi, oruku tindi tindi, oruku bi igba omo gbogbo won lo 
le tiro? Kino oo. This example of idiom teaches a lot of values and concepts in subjects like Elementary Science and Mathematics.

Teacher Gbemi Sch B (Agege) also supported the use of songs and rhymes as strategies to be used in teaching Yoruba in class:

I transmit the values in Yoruba through songs, dance, stories and rhymes. Yoruba stories connote much information about Yoruba culture and traditions. The school organizes excursion to historical places like Osun Osogbo shrine in Osun State of Nigeria to make the learners get familiar with the Yoruba cultural norms and traditions.

The researchers noted learners' comments about the excursion to Osun Osogbo shrine describing the experience from different perspectives which led to arguments amongst them. This however was not part of the researchers' study. Some learners commented in support of the excursion to such historical places in the nearest future for them to know more about the Yoruba culture and traditions while some other learners did not like the experience on religious grounds. A particular learner mentioned that her parents are Christians and was against going with other learners on an excursion to Osun Osogbo "shrine". To her parents it is a sin and that Almighty God forbids Christians to worship idols in shrines. This was the comment of the learner based on her parents' opinion on religious grounds however; excursion to the learners was a good experience because it afforded them the opportunity to have a first-hand information and real experience of what the teacher has taught in class.

\section{Attitude of Teachers towards Yoruba}

Horencyzk and Tatar (2002) opined that teachers' attitude towards culturally multi linguistic class population do not exist in isolation; rather, it tends to reflect and be affected by the values of the larger society and the school setting in which the interaction take place. Teacher participants in the study argued that when teachers internalise societal traditions and norms, they bring them directly into their classes, thus creating classrooms norms that reflect the values of the larger society.

In this section, teacher participants interviewed commented in different ways on how they value their teaching of Yoruba language.

Teacher Kemi Sch B (Agege) expressed her opinion that: 
It is a language of pride (ohun amu yagan ni Yoruba) and I attach so much importance to it.

Teacher Bayo Sch A (Badagry) said:

Yoruba as a language of learning and teaching in class is a veritable medium to promote our cultural background. I enjoyed teaching Yoruba language because of its richness in culture and tradition especially when I teach "orisirisi asa ni ile Yoruba" meaning teaching different traditions and customs in Yoruba land.

It was observed that teachers (Kemi SchB, Jide SchA, Bisi SchA, Bayo SchA) were passionate about teaching the Yoruba language from the way they teach Yoruba in class. There was passion in their voice and manner in which the integrated subjects were taught in Yoruba in class. Teachers' passion for teaching Yoruba and other subjects brought out their positive attitude towards the language. However the observation in class revealed that not all the teachers were passionate about the teaching of Yoruba. Teacher Bisi SchA expressed mixed feelings towards the teaching of Yoruba. Bisi SchA despite being passionate about the language, she also had her doubts about the language being going into extinction.

\section{Theme 2 - Challenges Regarding the Teaching of Yoruba}

The following categories are used

\section{Teachers' Fear against the Extinction of Yoruba}

The teacher is a major role player in the educational sector because he holds the key to the door of success hence the need for highly qualified teachers to be employed by the government. The shortage of teachers in the primary school system particularly indigenous language teachers in Nigeria calls for concern. The school chosen for the study in Badagry has only one primary 3 teacher to teach 72 pupils. This is contrary to the policy recommendation of ratio 1:25 of teacher to learners. All the respondents interviewed in the school complained that government should employ more teachers to teach in the school. The shortage of teachers made the head teacher and the two assistants to also teach everyday as if they were classroom teachers.

Teacher Bayo SchA (Badagry) stated: 
I love teaching Yoruba but the shortage of teachers makes me to be overworked, I am not supposed to teach due to my position as an assistant head teacher but I have to be involved. Teacher Bimbo SchB (Agege) commented on Yoruba going into extinction:

My concern is the way and manner Yoruba is going into extinction. The children don't speak the language fluently because it has been replaced with English.

It was observed (SchA and SchB) that the code switching strategy used by the teacher has its positive and negative effects on learners. The negative effect is that learners could not speak both languages (Yoruba and English) fluently. This attitude might affect the children's attitude towards Yoruba. The parents not collaborating with teachers might affect the teaching of Yoruba negatively. Simple Yoruba terminologies might seem far-fetched for children and might make the understanding of the language difficult.

In the field note it was noted that learners commenting among themselves said that their parents forbade them to speak vernacular at home. They only communicate with their parents in English. This corroborates the interview comment gathered from teachers on Yoruba language going into extinction.

\section{Attitude of Government towards the Development of Yoruba}

The Nigerian government pays lip service to primary education by not providing resources necessary for teaching the language (Afolayan 1999). The government stipulated the use of mother tongue as a medium of instruction in lower primary classes (FRN 2004) but does not monitor its implementation. Secondly, copies of the policy statements are not available to teachers to read and digest the contents in order for them to understand the teaching and learning procedures in classrooms. Some of the teachers like Jide in SchA and Kemi in SchB commented that only one copy is made available in schools for many teachers to share.

Teacher Jide SchA (Badagry) stated that:

The policy document needs to be provided to all teachers so that we can be well informed on the stipulation. As at now, there is only one copy available in the school.

Teacher Kemi SchB (Agege) also stated that:

The school cannot help in this situation due to the reality on ground. The policy document is not available to us to get familiar with. 
It was confirmed through observation (SchA and SchB) that one copy of the policy document was available for teachers in school and it was kept in the head teacher's office. The copy was very old and some pages missing.

For teachers to be well informed about the stipulations in the policy document, the Nigerian government needs to provide more copies of the documents for teachers to use in teaching and learning of Yoruba in class. This was highlighted in the comments of the teachers used in this study but despite all odds, teachers were able to use the few copies to teach effectively in class. The copies were used in turns after one another without any wrangling.

\section{Dire Teaching Conditions}

The dire teaching conditions in Nigerian primary school classrooms have an effect on teaching and learning in class. Teacher Jide SchA handles 72 learners in a class whereas if the classrooms are many, the learners would be spread on a ratio of 1 teacher to 25 learners (1:25) as stipulated by the policy. The same thing also applies to school B chosen for this study in Agege, where all the 66 learners were sandwiched in a classroom and the three teachers had to teach them one after the other. What this means is that the learners would have been divided into three classes and each class would have been handled by a teacher. There are inadequate toilet facilities, dilapidated buildings, leaking roofs and broken furniture (Situation and Policy Analysis of Basic Education SAPA, 1993).

Teacher Kemi SchB (Agege) commented thus:

...the classroom environment is not conducive for learning; instructional materials are not available. I made the ones I use myself from my meager salary.

Teacher Bimpe SchB (Agege) mentioned the following factors inhibiting the teaching and learning of Yoruba in schools:

Lack of funds, lack of furniture, dilapidated school building, shortage of staff and many others.

As we went around school in Agege chosen for the study, I t was observed that only one toilet was available and it was meant for the teachers while the learners were not catered for at all. It was also observed that the roofs of the classrooms were leaking and whenever it rained, 
lessons would be disrupted because learners would have to go into other classes to seek refuge while their teachers would also seek refuge in other offices.

On the academic side of teaching, the teacher respondents (Titi SchB, Bimpe SchB, Kemi SchB, Jide SchA) for this study mentioned the need for the government to provide them with the necessary instructional materials. The teachers through interview complained of lack of instructional materials like instructional aids, text books, and absence of magic boards to write while teaching in this $21^{\text {st }}$ century the schools had black boards which were already dilapidated.

Teachers Titi SchB, Kemi SchB, Bimbo SchB, Dupe SchB and Gbemi SchB (Agege) mentioned during interview the need for the government to provide them with necessary instructional materials for teaching. Speaking in the same vain teachers Jide SchA, Bisi SchA, Bayo SchA and Gbenga SchA (Badagry) agreed that the government needs to provide teachers with necessary instructional materials.

Lack of appropriate textbooks also hinders learning. During the collation of the data for this study it was observed that few textbooks were available and shared between two learners to one textbook. The few textbooks available were old and torn. Scholars observed that insufficient textbooks to support mother tongue education for the first three years of primary education, as prescribed in the policy on education has been a major setback towards achieving effective teaching and learning (Emenanjo et al. 2003).

\section{DISCUSSION}

The data revealed how the teachers enjoyed teaching Yoruba in class using various strategies to transmit the values to learners. The strategies used include inviting resource persons to talk to learners, using traditional songs, excursion to traditional places like the Osun osogbo shrine, proverbs, stories and rhymes. The values embedded in the Yoruba language were transmitted to the children through oral traditions, proverbs, songs and rhymes. This was corroborated by Adeosun (2008).

The attitude of teachers towards the use of the Yoruba language in teaching was revealed in the data in the way the teachers were passionate and identified with the language during teaching. Teachers emphasised the importance of home language through their daily instruction in class to learners and expressed their commitment to teaching the Yoruba language 
through the use of traditional examples like mode of dress. Researchers support this view by saying that personal identity is a synthesis of personal, social and cultural self-conception (Tajfel and Turner 1986; Schwartz 2001; Erikson 1968).

Teachers in the study experienced Yoruba as a language of learning and teaching as both positive and negative. They enumerated a number of challenges that affected how they taught Yoruba. However, these challenges were not confined to Yoruba teaching but affected the entire school life. This assertion is supported by Oduolowu (2000) in a study conducted on Nigerian schools. She said that the Nigerian primary school class environment is not conducive to learning.

Another challenge faced by teachers in the study was their fear that the Yoruba was becoming extinct. Christopher (2008) supports this assertion stating that this is due to the training of teachers and also because not enough teachers are available.

The data revealed that there were too few copies of policy documents to go round. Furthermore, some of the teachers complained that there were not enough textbooks available and that what was available were worn. Insufficient textbooks to support mother tongue education for the first three years of primary education as stipulated by the policy has been a major setback for achieving effective teaching and learning (Emenanjo et al. 2003).

Researchers argue that teachers and learners can use funds of knowledge to engage in critical pedagogy based on learners' resources rather than on their deficits (Gonzalez and Amanti 1992; Gonzalez and Moll 2002; Moll et al. 1992; Gonzalez et al. 1993; Velez-lbanez and Greenberg 1992).

\section{CONCLUSION}

This study is important because it brought out the actual happenings in the class thus letting us know the germane of Yoruba which is the mother tongue in this context and how primary school teachers used in the study were able to use it as a medium of instruction. Although many challenges were identified but the study made us to know that teachers were on top of the situation by making sure that learners irrespective of their ethnic and social background were taught Yoruba effectively. Learning through the mother tongue do not only preserve the cultural values of the people but makes learning permanent in the learners thereby develops in the 
learners' readiness to learn and affords the learners the opportunity to transfer learning appropriately.

The youths of today are the expected leaders of tomorrow hence they must be well groomed cognitively, socially morally and culturally; thus, education in mother tongue as highlighted in this study makes this achievable. The teacher as the facilitator of knowledge was examined through interview and observation and the results revealed that primary school teachers used in the study experienced many challenges while using Yoruba as a medium of instruction in schools but despite these challenges, they were able to teach Yoruba effectively. Learners were also able to cope with learning of Yoruba despite their different ethnic backgrounds.

\section{RECOMMENDATIONS}

The following recommendations were made to improve the use of Yoruba as a language of learning and teaching in primary classes.

- $\quad$ The Ministry of Education must ensure that policies are practiced as stipulated and that monitoring and supervision of teachers in the schools for proper implementation of the policy should be intensified.

- Secondly, training of indigenous language teachers need to be intensified and encourages; those teachers that have already been employed need to attend seminars and workshops on the latest methodologies and instructional materials that can be used in teaching. Such pedagogical materials can be suggested by teachers to effectively teach Yoruba and any other subjects well in classes.

- Teaching environment is important in how teachers identify with the schools and what they are employed to do. Shabby looking schools do not help in establishing positive identity in teachers. Some teachers felt demoralized because each time it rained, they fall behind with their work as children are sent home. Leaking roofs that allow rain to pour into the classroom or allow more than allowed sunlight to shine on learners books create a sense of rejection and lack of acknowledgement on what teachers can bring to the table. 


\section{REFERENCES}

Adeosun HO 2008. Yoruba child language performance: A prognosis. Anyigba Journal of Arts and Humanities, 6: 41-48.

Afolayan A 1999. The alienated role of the mother tongue in literacy education for sustainable national development: The western Nigerian Yoruba example. In: S Manaka (Ed.): Proceedings of the $1^{\text {st }}$ Pan-African Conference on Reading for All. Pretoria, South Africa: International Reading Association, READ and UNESCO/DANIDA.

Aubrey C 1997. Mathematics Teaching in the Early Years: An Investigation of Teachers' Subject Knowledge. London: The Falmer Press.

Ball J 2010. Enhancing Learning of Children from Diverse Language Backgrounds: Mother Tongue Based Bilingual or Multilingual Education in the Early Years. Prepared for UNESCO, Paris.

Bamgbose A 2011. African languages today: The challenges of and prospect for empowerment under globalization. In: G Eyamba, E Bokamba (Eds.): Selected Proceedings of the $40^{\text {th }}$ Annual Conference on African Linguistics. Somerville, MA: Cascadilla.

Barkley JR 2008. Making Sense of Place According to Lived Experience. United States of America. University of Illinois at Urbana-Champaign.

Barton AC, Yang K 2000. The case of Miguel and the culture of power of science. Journal of Research in Science Teaching, 37(8): 871-889.

Benson C 2002. Bilingual education in Africa: An exploration of encouraging connections between language and girls' schooling. Research Presentations at the Poverty Conference. New Education Division Documents 12. Stockholm: Sida. November 14, 2002.

Chilora H, Harris A 2001. Investigating the Role of Teacher's Home Language in Mother Tongue Policy Implementation: Evidence from IEQ Research Findings in Malawi. Malawi: Konga. Ministry of Education.

Christopher R 2008. Special Educational Needs and Inclusion: Reflection and Renewal. Hillscourt Education Centre, Rose Hill. Birmingham: NASUWT.

Cumming J 2003. Do runner beans really make you fast? Young children learning about sciencerelated food, concepts in informal settings. Research in Science Education, 33(4): 483-501. 
Cummins J 2001. Negotiating Identities: Education for Empowerment in a Diverse Society. $2^{\text {nd }}$ Edition. Los Angeles: California Association for Bilingual Education.

Creswell JW 2007. Qualitative Inquiry and Research Design: Choosing Among Five Approaches. $2^{\text {nd }}$ Edition. Thousand Oaks. CA: Sage.

Denzin NK 1992. The many faces of emotionality. In: C Ellis, MG Flaherty (Eds.): Investigating Subjectivity. Newbury Park, CA: Sage, pp. 17-30.

Dilthey W 1985. Poetry and Experience. Princeton, NJ: Princeton University Press.

Dutcher N 2003. Promise and perils of mother tongue education. In: N Dutcher (Ed.): Expanding Educational Opportunity in Linguistically Diverse Societies. Revised Edition. Washington DC: Centre for Applied Linguistics.

Emenanjo EN, Alajuruonye LN, Ikediashi AE, Okolie FO, Ugwuoke MI, Ikonne HU 2003. Participatory action research on the use of Igbo in Bende local government area of Abia State. UBE Forum. A Journal of Basic Education in Nigeria, 3: 138-146.

Erikson EH 1968. Identity: Youth and Crisis. New York: Norton.

Fafunwa AB 1977. Keynote address. In: A Bamgbose (Ed.): Introduction to Language in Education in Nigeria. Lagos: National Language Centre, P. 1.

Federal Republic of Nigeria (FGN) 2004. National Policy on Education. Yaba, Lagos. NERDC Press.

Fleer M 1997. The technical language children use at home. Early Childhood Folio, 3: 23-28.

Gonzalez N, Amanti C 1992. Teaching Ethnographic Methods to Teachers: Successes and Pitfalls. Paper Presented at the Annual Meeting of the American Anthropological Association, San Francisco. October 18 to 19, 1992.

Gonzalez N, Moll LC 2002. Cruzando el Puente: Harnessing funds of knowledge in the Puente project. Journal of Educational Policy, 16(4): 623-641.

Gonzalez N, Moll LC, Floyd-Tenery M, Rivera A, Rendon P, Gonzales R, Amanti C 1993. Report on Learning for Households: Teacher Research on Funds of Knowledge. Educational Practice Series. National Centre for Research on Cultural Diversity and Second Language Learning. Santa Cruz: CA.

Gupta A 1997. When mother tongue education is not preferred. Journal of Multilingual and Multicultural Development, 18: 496-506. 
Hancock DR, Algozzine B 2006. Doing Case Study Research: A Practical Guide for Beginning Researchers. New York: Teachers College Press.

Horencyzk G, Tatar M 2002. Teachers' attitudes towards multiculturalism and their perceptions of the school organizational culture. Teaching and Teacher Education, 18: 435-445.

Iyamu EO, Ogiegbaen SE 2005. On the mother-tongue medium of instruction policy curriculum innovation and the challenges of implementation in Nigeria. Language in India. 5(2); 75.

Kalu UK 1990. Re: No Way For Local Languages. National Concord. April, 19, P. 6.

Kosonen K 2005. Vernaculars in literacy and basic education in Cambodia, Laos and Thailand. Current Issues in Language Planning, 6(2): 122-142.

Lave J, Wegner E 1993. Situated Learning: Legitimate Peripheral Participation. New York: Cambridge University Press.

Littlewood W 1981. Communicative Language Teaching: An Introduction. Cambridge: Cambridge University Press.

Loveridge J 2004. Young childrens' learning in early education settings and at home: Mothers' understandings. Early Childhood Folio, 8: 2-8.

Moll LC, Amanti C, Neff D, Gonzalez N 1992. Funds of knowledge for teaching: Using a qualitative approach to correct homes and classrooms. Theory into Practice, 31(2): 132-141.

Oakes J 1985. Keeping Track: How Schools Structure Inequality. New Haven, CT: Yale University Press.

Oakes J 1990. Multiplying Inequalities: The Effects of Race, Social Class and Tracking on Opportunities to Learn Mathematics and Science. Santa Monica, CA: Rand.

Oakes J 2000. Course-taking and Achievement: Inequalities that Endure and Change. A Keynote Paper Presented at the National Institute for Science Education Forum, Detroit, MI, 22April.

Oduolowu E 2000. Preprimary and Primary Education in Nigeria. Ibadan: Akiode Publishers.

Olowoyo O 1990. Look Beyond Mother Tongue. Daily Sketch, June 28, 12.

Ross S 2004. The Mother Tongue in Morocco: The Politics of an Indigenous Education. Unpublished Masters of Arts Dissertation. Anglia: University of East Anglia.

Sartre JP 1957. Existentialism and Human Emotions. New York: Citadel Press.

Schwartz SJ 2001. The evolution of Eriksonian and neo-Eriksonian identity theory and research: A review and integration. Identity, 1: 7-58. 
Situation and Policy Analysis of Basic Education 1993.. Maximising the proximal learning factors in pre-school learning environment: A strategy to reclaim our children from risks. SAPA Report. Ibadan: Nigeria.

Skutnabb-Kangas T 1981. Bilingualism or not: The education of minorities multilingual matters. Multilingual Matters, 7: 28- 34.

Summer Institute of Linguistics (SIL) 1999. Introduction to sociolinguistics. Work Papers p43, United States of America: University of North Dakota Session.

Tajfel H, Turner JC 1986. The social identity theory of intergroup behavior. In: S Worchel, WG Austin (Eds.): The Psychology of Intergroup Behavior. Chicago: Nelson Hall, pp. 7-24.

Urevbu AO 2001. Curriculum Studies. Lagos: Juland.

Velez-lbanez C, Greenberg J 1992. Formation and transformation of funds of knowledge among US Mexican households. Anthropology and Education Quarterly, 23(4): 313-335.

Wolff HE 2005. Language and Language Policies in Africa: Problems and Prospects. Optimizing Learning and Education in Africa - The Language Factor: A Stock-taking Research on Mother Tongue and Bilingual Education in Sub-Saharan. Conference on Bilingual Education and the Use of Local Languages. Windhoek, Namibia: ADEA/GTZ/Commonwealth Secretariat/UIE. March 27 to 31, 2005.

Woolman DC 2001. Educational reconstruction and post-colonial curriculum development: A comparative study of four African countries. International Education Journal, 2(5): 27-46.

Wright T 1987. Roles of Teachers and Learners. Oxford: OUP.

Yadav R 1992. The use of the mother tongue in primary education: The Nepalese context. Contributions to Nepalese studies. CNAS Journal, 19(2): 79-85. 